Available Online at https://journal.unismuh.ac.id/index.php/otoritas

Otoritas : Jurnal Ilmu Pemerintahan, 9 (1), April 2019, 56-72

\title{
The Participatory and Responsiveness of Local Budget Policy in Malang, Indonesia
}

\author{
Salahudin ${ }^{*}$ ), Vissanu Zumitzavan², Achmad Nurmandi ${ }^{3}$, \\ Tri Sulistyaningsih ${ }^{1}$, Kisman Karinda ${ }^{4}$
}

\begin{abstract}
${ }^{1}$ Department of Government Studies, Faculty of Social and Political Sciences, Universitas Muhammadiyah Malang, Jl. Raya Tlogomas No.246 Malang, 65144, Indonesia. ${ }^{2}$ College of Local Administration (COLA), Khon Kaen University, 123 Mittraphap Rd, Nai Mueang, Amphoe Mueang Khon Kaen, Chang Wat Khon Kaen 40002, Thailand.

${ }^{3}$ Department of Government Affairs and Administration, Jusuf Kalla School of Government, Universitas Muhammadiyah Yogyakarta, Jl. Brawijaya, Bantul, Yogyakarta 55183, Indonesia.

${ }^{4}$ Department of Government Studies, Faculty of Social and Political Sciences, Universitas Muhammadiyah Luwuk, Luwuk, Banggai Regency, Central Sulawesi 94712, Indonesia.
\end{abstract}

Received: 30 January 2019; Revised: 16 March 2019; Accepted: 21 April 2019

\begin{abstract}
Since political reform in 1998, the Indonesian government has decentralized governance practices in order to provide a space for local governments to develop the local potential of each region. Consequently, the local government should be responsive to people's needs and more accountable for regional development. Therefore, local governments should be willing to involve local citizens in the public policy-making process. On the other side, local communities should actively engage in development processes, particularly in budget policy planning. This article reports on a study to determine to what extent the local government is responsive and accountable to the local citizens in Malang Municipality in Indonesia. A qualitative approach was applied to the process of data collection and data analysis. The results show that the local government has low responsiveness and accountability to local citizen's needs and local preferences. The findings reveal a lack of willingness on the part of local government to involve local citizens and civic groups in budget planning, and elected officials demonstrate little responsibility in arranging budget policy support to achieve social welfare, one of the main points of decentralization. These findings show that central government should pay more attention to improving the awareness of local governments and the capacity of local communities so that decentralization may be supported.
\end{abstract}

Keywords: Accountability; Decentralization; Local Government; Responsiveness

How to Cite: Salahudin, S., Zumitzavan, V., Nurmandi, A., Sulistyaningsih, T., \& Karinda, K. (2019). The Participatory and Responsiveness of Local Budget Policy in Malang, Indonesia. Otoritas : Jurnal Ilmu Pemerintahan, 9(1), 56-72.

Permalink/DOI: https://doi.org/10.26618/ojip.v9i1.1720

${ }^{*}$ Corresponding Author.

E-Mail : salahudinmsi@umm.ac.id

Copyright (C) 2019, Otoritas : Jurnal Ilmu Pemerintahan, ISSN: 2088-3706 (Print), ISSN: 2502-9320 (Online) 


\section{INTRODUCTION}

Responsiveness and accountability are fundamental components of democratic systems. Democracy is wellrecognized all around the world for enabling citizens to voice their aspirations through the vote (Hadiz R., 2004). Although it may not be an ideal political system, it offers a channel for citizens to voice their needs (Thomson, 1995). It plays a vital role in increasing citizen participation via elections. In principle, the higher the level of participation, the more democracy grows in a community.

In general, when considering the dynamics in a democracy, the concepts of 'decentralization' and 'participation' are well-recognized. Through various definitions exist, decentralization is here taken to mean the process by which all authority and responsibilities, whether political, fiscal, and administrative, are transferred from central government to local governments to take control over their affairs, including education, healthcare, infrastructure, and so on (Fossati, 2016; Kewo, 2017).

To understand the progress of decentralization, it is essential to see how much citizens can enjoy the level of participation in local government. Participation is one of the most straightforward elements of democracy. It shows a level of awareness on the part of citizens in a country or community in that they know how they are supposed to act via political activities and at the time of general elections (Craig Johnson, 2001). Political participation is a voluntary act, though in principle all citizens are required to exercise their rights by voting for their leader. Therefore, participation includes the aspirations, actions, intentions, interests, and willingness of citizens.

In addition, in nearly all democratic countries, the level of participation of citizens demonstrates the level of democracy of that country. The level of partici- pation in Western democracies may be observed through the complex levels of responsiveness of the citizens of each country (Lowndes, Pratchett, \& Stoker, 2003).In developing Southeast Asian countries, participation in democracy may be more theoretical. For example, in Indonesia, the central government has supported local governments by passing laws and providing a certain amount of grants annually to decentralize the authorities, responsibilities, and powers to local governments.

The central government passed two major laws for transferring powers to the local government known as Law Number $23 / 2014$ on local government and Law Number 33/2004 on Budget Balance Management. By doing so, the Indonesian central government provides wideranging authorities and powers for local governments to manage local governance independently and autonomously (Dixon \& Hakim, 2010). This means that local governments can, in theory, establish policies to build and empower their region without the directive role of the central government.

At the same time, the local governments are in principle, meant to attract local people to take part in making public policies (participative policy) so that these can answer the society's needs. In terms of providing budgets, the central government transfers the budget to the local governments annually in the form of the Dana Alokasi Umum $(D A U) /$ General Budget Allocation and Dana Alokasi Khusus $(D A K) /$ Specific Budget Allocation.

In 2015, the budget distributed by the central government to local governments reached approximately IDR 638.0 trillion, which is about $31 \%$ of national expenditure (IDR 2.039.5 trillion), while in 2016 it was approximately IDR 770.2 trillion, or about $35 \%$ of national expenditure (IDR 2.095.7 trillion). In 2017, it was approximately IDR 764.9 trillion, about $34 \%$ of national expenditure (IDR 2.080 .5 
trillion). This represents a considerable budget allocated by the central government to local governments. In all budgeting, the process of budget planning at the local government must be transparent and observable in order to encourage citizens to be involved in public policy processes (Hadi Sasana, 2017).

There is evidence that most Indonesian citizens are aware of the importance of participating in democracy and exercising their rights to improve the country through casting their votes and participating in speaking out and exercising their rights at both the local and national levels within the country, including in budget planning (Widianingsih \& Morrell, 2007). However, there is a need to better understand to what extent local governments are able to serve the needs of the local people, given the intention of the Indonesian central government to make it possible to transfer authority and power to the level of local government.

In addition, there is the need to understand to what extents the local government would be able to serve the needs of the local people even though it seems that there are great intentions of the Indonesian central government to make it possible for transferring authorities and powers to the local government.

In line with the laws of the government of Indonesia, the budget is the main delivery mechanism for public welfare. However, some inhibitory planning factors mean that the budget does not satisfy the communities' in terms of the level of participation. Firstly, the public lacks access to the budget planning cycle in order for them to be involved in the preparation of the Musrenbang (budget planning process) due to a lack of information and specific awareness of the process, as well as the decision of local government to limit the elements of the community allowed to become involved in planning forums. Secondly, the effective influence of political elites (regional legislatures or Dewan Per- wakilan Rakyat Daerah [DPRD] and local heads) directs the budget towards their own interests. Hence, raising the level of awareness of civic groups in Indonesia, which is related to the level of participation in budget planning, is imperative for improving the level of democracy (Sopanah, 2012).

This study may help to understand the level of democracy in Indonesia in the sense that any citizens in civic communities should participate in contributing to and conveying their needs in realizing their rights in relation to democratic conventions. This study investigated the level of responsiveness of the local government in transferring budgets to local communities or people, particularly in Malang. Malang City is a city in Jawa Timur Province. Geographically, Malang City has the second largest area in Jawa Timur Province. The area of Malang is $145.28 \mathrm{~km} 2$ while other cities include Surabaya (350.54 $\mathrm{km} 2$ ), Batu (136.74 km2), Kediri (63.40 $\mathrm{km} 2$ ), Probolinggo (56.67 km2), Pasuruan (35.29 km2), Madiun (33.92 km2), Blitar (32.57 km2), Mojokerto (16.47km2). In the Human Development Index context, Malang scores $80.05 \%$ which is better than the other cities of Jawa Timur Province namely Madiun City (79.48), Surabaya City (79.47), Blitar City (76), Kediri City (75.67), Mojokerto City (75.54), Pasuruan City (73.78), Batu City (72.62), and Probolinggo City (71.01) (Statistics Bureau of the Republic of Indonesia, 2017).

In addition, Malang City is composed of stakeholders playing vital roles in taking control of their own affairs based on the decentralization programme, including officials, the mayor, minorities, and civic groups. Hence, this city provides a case study for investigating the level of responsiveness and citizen participation.

The citizen participation issues can be explained trough democracy theory. In democracy theory, citizens should be more autonomous to take action and play 
a role in public policy processes. The theory of democracy is a form of a theory of citizenship as it supports, in principle, the autonomy and improvability of citizenship (Hammond \& Tosun, 2009). The citizens should take part in the processes of democracy. It is insufficient that the government should determine the highest social good. The most important aspect of democracy is that all citizens share in selecting their governors and in determining their policies. Moreover, Thompson (2010) adds the democratic system is supposed to be based on the autonomy of the people and the humanity of the citizen. Democracy needs skills and leadership, as well as the reference to the common humanity of all citizens. If the voice of citizens is not quite the voice of God, no one else has a better claim to speak for him.

Moreover, citizens have autonomy, public access, a free public sphere, and a free public. People should be independent of state interests, whether in the political, economic, or social arenas. Civil society should have an opportunity to access state agencies and state institutions (Fox, 2015). In this context, the relationship between the state and society, each citizen, either as individuals or in communities, should have an opportunity to access state institutions. The government should uphold the rights of the citizens through regulations or laws based on the values of democracy, such as justice, equality, and participation. As related to the values of democracy, the public sphere creates a relationship between the state and society in relation to public policy-making through the rule of law. Citizens understand the circumstances of their living environment, and they can become involved in public policy-making via the democratic process.

Thus, in most democratic countries, all around the world, the level of democracy can be observed through the level of citizen participation. One obvious exam- ple by which this can be measured is the level of participation of the citizens in their communities, such as their level of participation in budget planning.

Although in Indonesia laws have been passed to improve the level of citizen participation in terms of budget planning, they have not been well implemented. In particular, research has found that the relationship between local government and civic groups in budget planning at the local level in Indonesia does not reflect democratic values (Basri \& Nabiha, 2014). This is due to a lack of socialization on the part of city governments and parliament; the fact that the mechanism at development planning meetings is just ceremonial; and the fact that popular awareness of process, especially among middle and lower income groups, is still relatively low (Jurnali \& Siti-Nabiha, 2015; Sopanah, 2012).

Civic groups' access to active participation mechanisms is also undermined by the local government. Local government, from the executive (regional head and the administration officials) through to the legislative members (parliament), fully controls and directs the majority of budgetary policy. Consequently, budget policy does not incorporate citizens' needs (Basri \& Nabiha, 2014; Jurnali \& SitiNabiha, 2015; Sjahrir, 2014; Sopanah, 2012)

In Indonesia, even though a clear process for participation in budget planning exists, the level of citizen participation is low. Also, a collusive relationship can occur in a budget planning process (Basri \& Nabiha, 2014; Hadi Sasana, 2017; Yang, 2008). There may be associations between stakeholders involving them acquiring advantages from the process. The stakeholders include city governments, villages and sub-district governments, the local elite, the Rukun Warga: RW, or the Neighborhood Association, the Lembaga Pemberdayaan Masyarakat Kelurahan: LPMK, or the Community Empowerment 
Organization at the Village Level, and neighborhoods and communities.

This may suggest that there is no guarantee that no matter how good the process for budget planning is, or no matter how good the laws supporting the level of participation in Indonesia are, there remains an imperative disruptive factor, namely 'the collusive relationship' which intervenes to reduce the level of citizen participation and diminish the flourishing of democracy. Here, 'collusive relationship' is defined as two parties colluding for their common benefit (Smith, J., Obidzinski, K., Subarudi, S., Suramenggala, 2007).

In addition, when a low level of collaboration exists between local governments and stakeholders, such as citizens and private groups, this may generate a form of local governance not supportive of the need to achieve the goals of government institutions (Emerson, Nabatchi, \& Balogh, 2012). Therefore, Emerson, et.al (2012) suggests that the public policy process should be based on good collaboration among stakeholders. He calls this a form of principled engagement occurring over time and potentially including different stakeholders at different points, and taking place in either face to face or virtual formats, either crossing organizational networks or in private and public meet- ings, among others settings. Thus, in this case, study, the levels of engagement of citizens were observed in order to develop recommendations regarding how to encourage and engage citizens and communities to be involved in budget planning, which would then demonstrate a higher level of participation and in turn increase the level of democracy overall.

Moreover, to understand the level of democratic government can be seen the accountability of government by public policy that they make for people. The accountability of a local government is seen in its ability to serve the local people or citizens. Hence, all activities must be transparent and observable. In this study, we focus on budget planning, in which all citizens must be encouraged to participate in all pertinent procedures in order to ensure that the budget has been allocated legitimately (Lafont, 2015).

Encouraging and providing channels for citizen engagement are considered to be a means for connecting governments to their citizens. Simultaneously, decentralization is also a way to increase the level of responsiveness of citizens to be participants in activities held by local governments to proliferate the opportunities for citizen oversight and accountability (Carol Ebdon \& Aimee L. Franklin, 2006). Democratic countries require that citizens

Table 1. List of Budget

Source: Adapted from the Ministry of Finance of the Republic of Indonesia (2017)

\begin{tabular}{cccc}
\hline Year of Budget Policy & $\begin{array}{c}\text { The total Revenue } \\
\text { of Central Govern- } \\
\text { ment }\end{array}$ & $\begin{array}{c}\text { General Budget } \\
(D A U) \\
\text { (Trillion in Indone- } \\
\text { sian Rupiah: } I D R)\end{array}$ & $\begin{array}{c}\text { Specification } \\
\text { Budget }(D A K) \\
\text { (Trillion in In- } \\
\text { donesian Rupiah: } \\
I D R)\end{array}$ \\
\hline 2014 & $1.550,6$ & 341,2 & 33,0 \\
2015 & $1.761,6$ & 352,9 & 35,8 \\
2016 & $1.822,5$ & 491,5 & 208,9 \\
\hline
\end{tabular}


should meet the minimum standards of equality and autonomy. Individuals should have equal opportunities to show their views on political matters.

Therefore, a high level of participation of citizens is essential since this show the levels of responsiveness and accountability of the government, including the citizens' points of view. Hence, the more citizens are willing to participate, the more community can claim to be democratic (Levin-waldman, 2011). So, all democratic countries in principle strive for a greater level of participation from their citizens.

In addition, the relationship between local government and civic groups in the process of regional budgetary policy (budget planning) should be related to the democratic principles of justice, equality, propriety, and proportionality. Therefore, democratic values are fostered when public bodies and the implementation of government are open when opportunities and procedures are existent for civic groups to permeate the system, and when responsibility is assured (Basri \& Nabiha, 2014; Cabannes, 2005). Thus, this may suggest that when citizens in developing countries have a greater level of participation in budget planning, the level of democracy achieved will move closer to the level in developed countries, which are generally known as regions where democratic systems flourish.

Briefly, all the explanation above shows that a way to implement a democratic system is the central government should transfer and share power and resource to local government and communities. By the decentralization policy, local government has power and modality to manage their own regional authority. However, in this contexts more important one to understanding democratic system running well is how the local government utilizes the authority participative and responsively. In case, the local government involves local communities to take part in budget policy-making processes. Then, local officials and politicians of the local government approval budget policy taking a side to society and development regional needs. Therefore, the study on the issues is major academic projects conducted to capture the democratic system, and decentralization concept can be run successfully.

Meanwhile, there are fewer previous studies on the relationship between decentralization, participatory, and responsiveness. Most scholars explored that in the administrative context, decentralization can push the official local government to be more responsive to public affairs (Hammond \& Tosun, 2009; Sjahrir, 2014; Yang, 2008). At the same time, politics area of decentralization like participatory budgeting issues at the local level is known that local government has been less involving local communities in the budget-making process (Cabannes, 2005; Fossati, 2016; Sjahrir, 2014; Widianingsih \& Morrell, 2007). Even though, some scholars assert that decentralization governance cannot be divided from both participatory and responsiveness issues. Both of them are a unit of the decentralization system (Craig Johnson, 2001). Therefore, they suggest that scholars need to conduct a study on decentralization into two contexts that are participatory and responsiveness governance at the same project of research (Dixon \& Hakim, 2010). It is due to that the decentralization system can be implemented successfully if the local government is implemented in a participatory manner and responsively (Emerson et al., 2012). This research takes place to explore the participatory and responsiveness of local government in Malang, in decentralization context.

The level of responsiveness of the local government was studied through the decentralization concepts related to the level of citizen participation by observing their engagement in the budget planning 
process. Therefore, this paper aims to what extent participatory and responsiveness of local government in Malang in decentralization system.

\section{RESEARCH METHODS}

Qualitative methodology was applied in this study to examine the issues of dynamic political processes in budget planning. The varying dynamics mean that the actors involved in the budget process hold different perspectives and interests regarding budget planning. Therefore, to understand the dynamic political processes of budget planning, it is necessary to take part in the field according to the principles of qualitative method. In line with this argument, we explored the objectives of this study by understanding through field research the background and dynamics of key actors, such as elected officials and social activists.

Data collection was conducted by firstly, observing activities of budget plan- ning processes (observation). All the stages of the budget planning process were observed, such as the public hearing process (Musrenbang), meeting, and discussions between government officials and members of the legislature on the approval of the budget to enact legislation on budget policy.

Secondly, interviewing key persons (interview), in which the participants were members of the legislature, three government administrators, and social activists belonging to civic groups. In this study, participants were interviewed through face-to-face interviews taking place at the offices of the participants.

Thirdly, taking documents related to the budget policy of the local government. Documents were also obtained to support the evidence gathering process, including local government laws on budget planning, documents on local government, documents on civic group participation, and so on.



Figure 1. The Local Budget Planning Process in Indonesia

Source: Salahudin, Jainuri, \& Nurmandi (2017) 
Main data collection occurred from the middle of March until the end of July 2016. Several sources of data, including interviews, observation, and documents, were obtained in 2015 via a precursor round of data gathering.

The data of this research was analyzed through Creswell's approach, namely: organizing data, reading and memoing documents, describing the phenomena, classifying data, and interpret the data into the code and the theme, interpreting data, and present and visualize data (Creswell, 2017).

The location of this research was Malang, Indonesia. Malang is well-known as a city of education in Indonesia due to the existence of several lower and higher educational institutions comprising both formal and informal public and private education institutions, from pre-school institutions to higher education including colleges. In addition, several independent organizations that are part of civil society exist there, such as NGOs, political parties, private education institutions, Civil Society Organizations (CSOs), the Activists Education Association, and the Association of Trading Communities.

The circumstances mentioned above are the reasons why the researcher selected this city as the research location. In this study, the researcher described the abilities and capacity of the civic groups of Malang City in the formulation of the regional budgetary policy of the city government, i.e., whether the many civic groups in Malang City are able to balance the power of the state (Malang's local government) and to what extent the civic groups are able to determine regional budgetary policy. However, there is a corruption case that makes the Malang government needs to research deeply. The corruption case involved a mayor, 21 members of the local representative, and 2 officials of the government. All of them have been becoming suspect people due to they used their power to make budget policy going to personal interest. In case, the local government doesn't have a strong commitment to being responsive and accountable officials and politicians to people. Therefore, this paper takes place to explore the issue.

\section{RESULTS AND DISCUSSION}

\section{Participatory Budgeting of Local Gov- ernment (Musrenbang Process)}

Implementing good governance in practice requires public participatory and accountability in governance practices. One of the goals of public participatory and accountability in Indonesia has been reforming the public finance sector. Since the beginning of political reform in 1998, Indonesian stakeholders have reformed the budgeting system centralistic paradigm to one of a decentralized system. The main mechanism in the financial sector is to focus on the budgeting system to reform budgeting in a change from traditional budgeting to performance basedbudgeting (Sentanu, 2015).

Before political reform in 1998, local government in Indonesia was governed by a centralistic power (centralization system). Therefore, the central government was powerful and exercised authority in managing, arranging, and making public policies for local level affairs in terms of the budget planning processes. Central government traditionally played the roles of initiator, planner, and executor of development policies (Widianingsih, 2015). Local governments were positioned merely as mediators of programs designed by the central government. In this regard, development planning in Indonesia has followed complex stages, with elite and bureaucratic domination devolving from national to subvillage levels.

In the era of political reform, Indonesia decentralized the system so that local governments have more power and greater authority in managing their own 
local resources, including the budget planning process. In this regard, decentralization in the Indonesian context in principle permits regional flexibility and the opportunity to initiate policies and programs relevant to local conditions (Sjahrir, 2014). Consequently, local governments now have much more freedom to make plans and set priorities to spend money by considering the aspirations of the local community through local legislatures, and less the interests of central government (Hadiz R., 2004)

In line with the definition of the decentralisation system, the regulation of the Minister of Domestic Affairs of Republic Indonesia, No. 13/2006, concerning guidelines for the preparation of the local budget, states that budget planning at the local level is based on mechanisms of participation in which citizens are involved in all stages of the budget planning. As stated by the law, the mechanism for devising local budget policy starts with the formal 'Discussion on Development Plan' (Musrenbang) at the village level from January to February, followed by the Musrenbang process at the sub-district level from March until May, then the Musrenbang process at the district Level from June to August. This is followed by the ceiling setting stage of the annual budget (Plafon Prioritas Anggaran Sementara: PPAS) and the policy stage of the annual budget preparation process. These lead to the approval of the local budget in the form of a 'Local Regulation' (Perda) from August until December. This mechanism is shown in the following chart.

In line with data obtained during the fieldwork, the stages of budget planning were unsuccessfully implemented consistent with the principles of a democratic system and participatory budgeting as described in the literature. Budget planning at the level of local occurs without involving democratic values and a proper commitment on the part of local government to arranging the budget based on people's needs.

For instance, one appointed official noted, "The local government involved local communities in the budget planning process. However, the interests of the people were not fully accommodated by the local government." Fundamentally, local government builds a collusive relationship among powerful stakeholders in the budgeting processes. The local government aims to create a budget policy serving their interests and needs. One politician in the local parliament explained, "The results of the budget planning appear to demonstrate a low commitment to serving as a reference budget policy. The mayor has to understand the interests of the elite; if not, the preparation of the budget policy may not proceed well, and it may cause several protests. Consequently, the mayor fully understands this and follows the political climate." Collusive relationships in the form of partnerships occurred throughout the budget planning process, from the village stage to the approval of the budget.

Based on the informant's explanations above, there are critical problems that occurs in budget planning of local government. The critical problems of that are:

\section{The lack of public participatory}

During activities research in the field, we found that civic groups as representatives of citizens do not have access to participation in the budgeting process. Hence, one activist of the Learning Community Forum (of Malang, or FMPP) lamented, "People have never been involved, even the organizers of public participation. Local government already involves the community leaders, but it is just a normative commitment. Even if there is the programme, they are not really completed for the reason of limited budgets. Even if there is one, it is not in accordance with the quota (programs) filed by communities." In this context, what is being 
demonstrated is 'passive participation' (Lafont, 2015).

Results show that participatory budgeting in Malang has not been successfully implemented. This is consistent with the findings of Basri \& Nabiha (2014); Jurnali \& Siti-Nabiha (2015); Sjahrir (2014); Sopanah, (2012). They established that local government understands that civic groups have only a minor role in the budgeting process. Consequently, participants perceive that the local government does not appreciate their involvement. Hence, this creates public frustration. They propose that citizens can feel isolated from public administrative processes. Although they care about the issues facing their communities and the nation, citizens feel "pushed out" of the public process. In the case of Indonesia, increasing community participation is not supported by consistent commitment of the local government.

In line with the evidence, Widianingsih \& Morrell (2007) Indonesian government has reformed budgeting system regulation, from a top-down approach system to bottom-up mechanism, in which the budget planning of local government is conducted participative. All local citizenships can be participating in budgeting processes. However, Widyaningsih found that local government tends showing and conducting budget planning without public participatory. In case, Sopanah (2012) also mentions that the local government did not have a strong commitment to implementing participatory budgeting at the local level. Our study strengthens research finding of both scholars, in which we reveal that the local government of Malang arranges the budget policy without involving the real citizens of Malang. It occurs, from the first stage to the last level of budgeting.

According to Basri \& Nabiha (2014); Hadi Sasana (2017), this deficiency occurs because local legislature perfor- mance is based mostly on party needs rather than community needs. Regarding these cases, Rebecca Rumbul, Parsons, \& Jen Bramley (2018), in their research, shows that the budgeting system cannot be implemented successfully is due to strong power of government officials and politicians in which they effort to dominate all stages of budgeting processes. The goals of their cooptation in the processes are to get and capture the budget policy going to their interests, whether personally or collectively. In the other side, civic groups do not have a strong position in the budget planning, even the regulations give them chances to take a side of all processes of budgetmaking processes. In this context, they assert that the fundamental problems of participatory budgeting are elite capture and cooptation at all levels of budgetmaking processes. During implementing of this research, we find that the local government officials have political strategies to reduce the public participation in budgeting processes. They design budgeting activity, in which citizens can not take part in the activities. One way of that is the officials of local government invite elites of civic groups to attend the budgeting events at the local government offices. One informant of this research said that "the local government officials of Malang have good tactics to mobilize communities to be passive people, there are no voices of civic groups to ask content of budget policy draft." It strengthens that the implementation of participatory budgeting has run unsuccessfully.

In line with the research findings, Sopanah (2016), a researcher of Indonesia, exposes that the bottom-up approach of budgeting-making processes that is a difficult system to be implemented in governance practices, because it needs strong goodwill all stakeholders who have power and authority whereas nowadays the top 
leaders of government at the local level did not have the vision to improve citizen participatory. Therefore, Sopanah (2016) mentions that participatory budgeting runs formally. Berenschot (2018), a foreign scholar, has studied on the economic development of Indonesia. He said that the most crucial problem of Indonesia is there is a political intervention of personals clientelism that is politicians and business personals. The actors control overlapping the budgetmaking processes. They come and sit together in the official meeting to arrange the budget policy based on their preferences. Therefore, Berenschot (2018) notes what occurs in the budgeting processes of Indonesia that is Politico Business Elites (PBE). Then, Sheely in his research finds that domination of elite roles in budget planning making the content of the policy going to politics elites personally and collectively.

2. The collusive relationship between politicians and officials of the local government in budget planning

The second problem of the budget planning is there are collusive practices of politicians and officials of the local government. These cases run massively during the budget planning processes. Members of the local parliament as political actors push the mayor, head of local government units, and other officials who are taking part in the budget processes. One of the aims action is the politicians want to the officials accommodating interests of the members of local parliament. In the other side, the officials also have the same as politician's interests, in which the public servants want to get some benefits that are personal interests, not the public needs. Therefore, both of the legal institutions build politics agreement to protect the collusive commitment. Some scholars said that the collusive relationship between the executive and legislative members in the budget planning occurs commonly around the local government of Indonesia, particularly in Malang.

The current corruption case of the Malang government shows there are collusive governances in Malang, in which due to a conspiracy of officials and politicians of the local government. The case involves a mayor, the secretary of executive government, ahead of government units for infrastructure affairs and twenty members of the local representative institution. The corruption had been begun with a mayor of Malang government who bribes chief of the local parliament, in which the mayor gives IDR 700 million to the politician. The main point of the mayor doing that mayor want to members of local representative approval some big projects and budget for these. Then, the chief of parliament distributes the money to some politicians of the legislative assembly. Therefore, all politicians of house representative approval the budget planning consisting of big projects, the budget support these as well.

The spoilage above shows that there is collusive relationship between official executive and politicians of local house representative. It confirms the research findings of some scholars who asserted that in the decentralization era, the local government and politicians have powerful position in governance affairs, particularly in budgeting processes. It gives big chances for them doing what they want to achieve in public policy (Berenschot, 2018; Cabannes, 2015; Rebecca Rumbul et al., 2018). Even though the scholars study on budgeting processes in different countries which Berenschot (2018) conducts his research in Indonesia, then Cabannes (2015) holds his study in Peru, and Rebecca Rumbul et al. (2018) carries out their academic project in Mexico, they have similar findings of their studies. In this context, they found that 
the budgeting-making processes have been revolved by collusive actions of political elites, officials government, and personal business.

Shortly, the budget-making policy processes of Malang have not made the participatory budgeting running well in the field. The issues are shown through the lack of citizens participation and collusive linkage between the public servant of the government and politicians of legislation institution. In case, all these problems are caused by the low commitment of the government to implement participatory budgeting successfully.

\section{Responsiveness of Local Government in Budget Planning}

Our interview analysis reveals that Malang government implements budget planning that is not based on the participatory budgeting concept in which citizens participate actively in all the stages of determining budget policy. This research also demonstrates that the local government had low levels of accountability in participatory budgeting as a government system to achieve good public services, social welfare, and justice at the local level. The findings confirm the results of other research studies conducted by a number of scholars in this area such as Basri \& Nabiha (2014); Dixon \& Hakim (2010); Fossati (2016); Fox (2015); Hadi Sasana (2017). All these scholars note that the policy of decentralization does not yet embody the delivery of good quality local public services. The new system is still not well-integrated into the Indonesian budget planning processes.

The vision of the decentralization policy is to improve local government performance in terms of responsiveness to local people. In this context, responsiveness refers to how local government arranges a budget policy for promoting people's needs and local preferences, such as public goods, public services, civic edu- cation, people's health, and poverty alleviation (Yang, 2008). Therefore, the Indonesian government under the decentralization system should pay attention to society's needs in the formulation budget policy. In line with the concept of responsiveness in the context of decentralization, the positive impact of fiscal and administrative decentralization Indonesia, as it increases the responsiveness of local governments to local public infrastructure coverage. However, many local governments in Indonesia, including in Malang, formulate budget policy in a direction that does not balance administrative expenditure and social development. This means that the local government lacks responsiveness to local development issues.

In effect, based on Regulation Number 13 of 2006 on financial management, which concerns budget management is at the local level, the budget is to fund the implementation of government affairs under the authority of the government of Malang. The budget consists of compulsory expenditure, alternative expenditure, and expenditure related to a particular field that could be implemented jointly by the government of Malang and other local governments. Funding for the implementation of the three areas mentioned is also known as local expenditure. This is divided according to expenditure categories, consisting of indirect and direct expenditure. Direct expenditure is directly related to productivity or activities regarding the organization's objectives. Direct expenditure when referring to personnel expenditure consists of wages to be paid by the government to employees; if employees do not do the job, they will not be paid. Indirect expenditure is interrelated to productivity or organizational goals. Indirect expenditure in regard to personnel expenditures consists of salaries paid to government employees but not based on labor productivity. The total of indirect and direct expenditure for the budget of Malang government for 
the fiscal year 2015 is shown in the following table 2.

Essentially, direct budget expenditure is to support regional development in Malang. However, if the budget is analyzed carefully and critically, the direct expenditure according to the structure of the budget does not directly encourage the establishment of regional development. Based on the results of interviews with a member of the legislature, with activists from civic groups, and with government administrators, the items of the budget included in direct expenditure budget on each Local Government Units (SKPD) are not based on necessity and proportionality.

Generally, the low responsiveness of local government accours around regionals of Indonesia. Sentanu (2015), in his research on gender responsiveness budgeting (GRB), found that the regional budget policy has not to support gender issues. Every year of budget policy is always less attention of local government for the field. He found that the government has not become the issue as main of budget policy. Then, some studies on the topic also exposed that neither national governments nor regional government has lack commitment to people needs and preferences (Galizzi, Bassani, \& Cattaneo, 2018).

Moreover, other findings of this paper revealed that the majority of local governments in Indonesia spend their budget on routine activities, mainly for the salaries of employees. This leaves a relatively small amount to the development expenditure of the budget. In most of the cases, this is not even enough to maintain the existing infrastructure. Hence, the local infrastructure deteriorates and hinders local economic growth. In line with the findings, Sjahrir (2014) in his study online with this issue, the relationship between fiscal decentralization, local elections, and regional development, showed that the budgetary effects of the democratization process are less clear. He found no favorable investment effects of either the previous introduction of party representation-based democratization or the later introduction of direct elections. If anything, responsiveness might have deteriorated in the health sector after the introduction of direct elections.

The legal regulations of the Indonesian government have already provided the public with an opportunity to become involved in state policies, including in the budget policy process. Nevertheless, the regulations and laws have not been optimally implemented due to little actual responsibility being shown by the government, especially by members of legislatures as representatives of the people. To support democracy and make government responsive to citizen needs, it is not enough to simply carry out government through further decentralization and democratization (Dixon \& Hakim, 2010; Hammond \& Tosun, 2009; Sjahrir, 2014). There is also a specific need to deepen and improve the capacity of civil society

Table 2. Total of Direct and Indirect Expenditure for Fiscal Year 2015 of Malang Government

Source: Adapted from the Local Budget Policy of Malang Government (2018)

\begin{tabular}{cccc}
\hline $\begin{array}{c}\text { Total Budget 2015 } \\
\text { (IDR) }\end{array}$ & $\begin{array}{c}\text { Total Expenditure } \\
\text { (IDR) }\end{array}$ & $\begin{array}{c}\text { Direct Expenditure } \\
\text { (IDR) }\end{array}$ & $\begin{array}{c}\text { Indirect Expenditure } \\
\text { (IDR) }\end{array}$ \\
\hline $\begin{array}{c}1,396,042,125,492,8 \\
7,\end{array}$ & $\begin{array}{c}1,490,561,138,516,9 \\
8\end{array}$ & $750,610,835,576,05$ & $739,950,302,940,93$ \\
\hline
\end{tabular}


to engage with decentralized state structures.

To strengthen civic groups' efforts, Carol Ebdon \& Aimee L. Franklin, (2006) suggests initiating efforts to build capacity among civil society organizations to take on citizen education and motivation tasks. In Malang, several civic groups focus on building civil society's capacity and on organizing people in terms of political education. Political education is considered to be an important force in building a collective consciousness to become a hegemonic force to balance the power of the dominance of the state (local government) (Widianingsih, 2015). Malang Corruption Watch (MCW), a civic group in Malang, organizes citizens by establishing a forum, namely the Forum Masyarakat Peduli Pendidikan (FMPP). The FMPP is under the supervision of MCW. One activist for the political education and anticorruption measures of the MCW explained, "The FMPP was established to carry out the functions of monitoring and advocacy, especially in the field of education." Therefore, the goal of the FMPP is to balance the power of the government and politicians in Malang in the preparation, implementation, and evaluation of policies, including the budget policy. The partnership between FMPP and MCW is a testament to the vision and mission of ensuring good governance for the benefit of society, i.e., the public interest. Regarding this explanation, Arvidson, Johansson, \& Scaramuzzino (2018) assert that the pivotal roles of civic groups are to criticize the government for social welfare and social justice take account to people and communities. In this context, civic groups can push the government to arrange the budget policy for society and regional improvement.

\section{CONCLUSION}

As we have seen through the lens of this case study, decentralization refers to the process by which central govern- ments transfer their powers and responsibilities to lower hierarchical chain of commands, referred to as local governments. The idea of the decentralization is to make it possible for the central government to provide better governance as local government is generally understood to be more aware of, and therefore capable of serving, local citizens' needs. Decentralization is also meant to encourage the development of democracy. Thus, transferring power to Indonesian districts and municipalities in principle makes government more responsive to local communities and placates the critics of centralized rule. In practice, there remain obstacles that the central government should address.

The results of this study show that the level of participation of citizens in the local community remains low. This appears to be because of the following reasons. Firstly, local government officials do not consider civic groups and citizens as key participants in the budget planning process. Secondly, collusive power is exercised between the local government and individuals who have stakes in budget planning. Thirdly, there is an imbalance in the budget allocation processes since local officials do not provide sufficient budgets to maintain all the important facilities in local communities.

Briefly, this paper asserts that there are two big problems of budget planning of Malang government that are weak of citizen participatory and less responsiveness of local government. Hence, the central government may need to be aware of the need to create mechanisms for prioritizing the most important parties to be involved in the budget planning process, i.e., local citizens, since they are the most important group of stakeholders and know most about the needs of their own communities. This does not mean taking back power, as prioritizing important facilities may be very challenging for the central government since the needs of 
each community may be different from place to place. Instead, providing channels to communicate with citizens may be ways to enhance the level of understanding of the needs of local citizens as these would serve as means for the government to announce upcoming activities and so increase citizen participation in policy decision making. Hence, understanding the needs of local citizens is crucial to allocate a sufficient and proper budget for each community-derived plan. Lastly, since collusive power intervenes in the process of budget planning, it may be necessary for the central government to authorizing honest person from central government to oversee and audit the process of budget planning to prevent collusive relationships.

Future research should emphasize longitudinal studies to understand whether, and how, the situation in Indonesia regarding decentralization is changing. Secondly, it would be fruitful to replicate this study in different regions of Indonesia in order to see whether the results are confirmed. Further, in-depth research requires examining Indonesian local governments which are developing best practices in civic participation in decentralizing fiscal responsibility as well as obtaining lessons from those areas where civic participation in fiscal decentralization may never have developed or has wholly broken down. Finally, the more detailed data obtained if this research agenda is implemented would then support future quantitative studies to analyses the dynamic relationship between stakeholders in multiple regions in Indonesia.

\section{ACKNOWLEDGEMENT}

We would like to thank rector of Universitas Muhammadiyah Malang, Director of Jusuf Kalla School of Governtment, Universitas Muhammadiyah Yogyakarta, and Dean of College of Local Administration, Khon Kaen University who have supported this research.

\section{REFERENCES}

Arvidson, M., Johansson, H., \& Scaramuzzino, R. (2018). Advocacy Compromised: How Financial, Organizational and Institutional Factors Shape Advocacy Strategies of Civil Society Organizations. Voluntas, 29(4), 844$856 . \quad$ https://doi.org/10.1007/ s11266-017-9900-y

Basri, H., \& Nabiha, A. K. S. (2014). Accountability of Local Government: The Case of Aceh Province, Indonesia. Asia Pacific Journal of Accounting and Finance, 3(31), 1-14.

Berenschot, W. (2018). The Political Economy of Clientelism: A Comparative Study of Indonesia's Patronage Democracy. Comparative Political Studies, 51(12). https:// doi.org/10.1177/001041401875875 6

Cabannes, Y. (2005). Participatory budgeting: a significant contribution to participatory democracy. Environment and Urbanization, 16(1), 27-46. https:// doi.org/10.1630/095624704323026 133

Cabannes, Y. (2015). The impact of participatory budgeting on basic services: municipal practices and evidence from the field. Environment and Urbanization, 27(1). https:// doi.org/10.1177/095624781557229 7

Carol Ebdon, \& Aimee L. Franklin. (2006). Citizen Participation in Budgeting Theory. Public Administration Review, 66, 437-442.

Craig Johnson. (2001). Local Democracy, Democratic Decentralisation and Rural Development: Theories, Challenges and Options for Policy. Development Policy Review, 19(4), 521-532. Retrieved from http:// dx.doi.org/10.1111/1467- 
Available Online at https://journal.unismuh.ac.id/index.php/otoritas

Otoritas : Jurnal Ilmu Pemerintahan, 9 (1), April 2019, 71

\subsection{9}

Creswell, J. W. (2017). Research Design Qualitative, Quantitative, and Mixed Methods Approaches. SAGE Publications International Educational and Professional Publisher. Retrieved from https:// pdfs.semanticscholar.org/73b7/18e5 08fa943dfb22a9cb5fb17f888239ad0 e.pdf

Dixon, G., \& Hakim, D. (2010). Chapter 9 Making Indonesia's budget decentralization work: The challenge of linking planning and budgeting at the local level, 10(1), 207-245. https:// doi.org/10.1108/s0732-1317(2009) 0000018011

Emerson, K., Nabatchi, T., \& Balogh, S. (2012). An integrative framework for collaborative governance. Journal of Public Administration Research and Theory, 22(1), 1-29. https:// doi.org/10.1093/jopart/mur011

Fossati, D. (2016). Is Indonesian Local Government Accountable To the Poor? Evidence From Health Policy Implementation. Journal of East Asian Studies, 16(03), 307-330. https:// doi.org/10.1017/jea.2016.17

Fox, J. A. (2015). Social Accountability: What Does the Evidence Really Say? World Development, 72, 346-361. https://doi.org/10.1016/ j.worlddev.2015.03.011

Galizzi, G., Bassani, G. V., \& Cattaneo, C. (2018). Adoption of GenderResponsive Budgeting (GRB) by an Italian Municipality. Administrative Sciences, 8(4), 68. https:// doi.org/10.3390/admsci8040068

Hadi Sasana. (2017). Regional Budget Anomaly in Regional Government in Indonesia. In The 4 Sebelas Maret International Conference on Business, Economics, dan Social Sciences (pp. 53-60). Semarang: Universitas
Sebelas Maret. Retrieved from http://eprints.undip.ac.id/64337/

Hadiz R., V. (2004). Decentralization and Democracy in Indonesia: A Critique of Neo-Institutionalist Perspectives. Development and Change, 35(4), 697718. Retrieved from http:// dx.doi.org/10.1111/j.0012155X.2004.00376.X

Hammond, G. W., \& Tosun, M. S. (2009). The Impact of Local Decentralization on Economic Growth: Evidence from U.S. Counties.

Jurnali, T., \& Siti-Nabiha, A. K. (2015). Performance Management System for Local Government: The Indonesian Experience. Global Business Review, 16(3), 351-363. https:// doi.org/10.1177/097215091556992 3

Kewo, C. L. (2017). The Influence of Internal Control Implementation and Managerial Performance on Financial Accountability Local Government in Indonesia. International Journal of Economics and Financial Issues, 7(1), 293-297.

Lafont, C. (2015). Deliberation, participation, and democratic legitimacy: Should deliberative mini-publics shape public policy?. Journal of Political Philosophy, 23(1), 40-63.

Levin-waldman, O. M. (2011). Income Inequality and Disparities in Civic Participation in the New York City Metro Area.

Lowndes, V., Pratchett, L., \& Stoker, G. (2003). Trends In Public Participation: Part 1 - Local Government Perspectives. Public Administration, 79 (1), 205-222. https:// doi.org/10.1111/1467-9299.00253

Rebecca Rumbul, Parsons, A., \& Jen Bramley. (2018). Elite Capture and Cooptation in Participatory Budgeting in Mexico City. IFIP International Fed- 
Available Online at http://journal.unismuh.ac.id/index.php/otoritas

Otoritas : Jurnal Ilmu Pemerintahan, 9 (1), April 2019, 72

eration for Information Processing 2018, 8654, 103-114. https:// doi.org/10.1007/978-3-662-449141

Salahudin, S., Jainuri, J., \& Nurmandi, A. (2017). Is There Civic Groups Participation in Budget Planning? A Study Budget Planning in Malang City, Indonesia. Jurnal Studi Pemerintahan, 8(2), 228-253.

Sentanu, I. G. E. P. S. (2015). Increasing Trust in Local Government Financial Management and Building Integrity: Efforts Reform in Indonesia. Public Policy and Administration Research, 5 (3), 206-213.

Sjahrir, S. (2014). The impact of fiscal and political decentralization on local public investments in Indonesia.

Smith, J., Obidzinski, K., Subarudi, S., Suramenggala, I. (2007). Illegal logging, collusive corruption and fragmented governments in Kalimantan, Indonesia. A book chapter in: Illegal Logging: Law Enforcement, Livelihoods and Timber Trade. International Forestry Review, 5(3), 293-301.

Sopanah, A. (2012). Ceremonial Budgeting: Public Participation in Development Planning at an Indonesian Local Government Authority. Journal of Applied Management Accounting Re- search, 10(2), 73-84.

Sopanah, A. (2016). Refusal of a local goverment budgeting: an interpretive case study. Asia Pacific Journal of Accounting and Finance, 1(2), 165177.

Thomson, J. T. (1995). Community institutions and the governance of local woodstocks in the context of Mali's democratic transition. 38th Annual Meeting of the African Studies Association.

Widianingsih, I. (2015). International Technical Assistance for Local Governance Reform in the Post-Suharto Indonesia: Sustaining Aid Effectiveness ?, 265-279.

Widianingsih, I., \& Morrell, E. (2007). Participatory planning in Indonesia. Policy Studies, 28(1), 1-15. https:// doi.org/10.1080/014428706011213 20

Yang, K. (2008). Responsiveness in Network Governance: Revisiting a Fundamental Concept: Symposium Introduction. Public Performance \& Management Review, 31(2), 131-143. https://doi.org/10.2753/pmr15309576310200 